УДК 159.9.07-177.7

о.О. СТАВИЦЬКИЙ, Д.О. СТАВИЦЬКИЙ

\title{
ПСИХОСЕМАНТИЧНІ АСПЕКТИ ДОСЛІДЖЕННЯ МОРАЛЬНОЇ СВІДОМОСТІ
}

Стаття присвячена аналізу результатів емпіричного дослідження рівнів розвитку моральної свідомості студентів гуманітарного профілю навчання з використанням психосемантичної методики Л. Кольберга (дев'ять дилем оціночного характеру норм і правил моралі). Використання психосемантичних методик дозволяє просто і зручно створити математичну модель індивідуальної свідомості - семантичний простір, як систему ознак, які описують об'єкти певної дійсності. Виявлено, щзо студенти демонструють різні рівні розвитку моральної свідомості залежно від актуальної ситуації. Водночас, афішуючи преконвенційний, конвенційний $і$ постконвенційний рівень 
одночасно, обираючи їх відповідно до ситуачії, студенти переважно знаходяться на високій стадії їх сформованості.

Ключові слова: особистість, моральна свідомість, студент, метод, психосемантика, емпіричне дослідження, преконвенційний рівень, конвенційний рівень, постконвенційний рівень, поведінка.

Статья посвящена анализу результатов элпирического исследования уровней развития нравственного сознания студентов гуманитарного профиля обучения полученных с помощью психосемантической методики Л. Кольберга (девять дилемм оценочного характера норм и правил морали). Использование психосемантических методик позволяет просто и удобно создать математическую модель индивидуального сознания - семантическое пространство как систему признаков, описывающих объекты определенной действительности. Выявлено, что студенты демонстрируют разные уровни развития нравственного сознания в зависимости от актуальной ситуачии. В то же время, афишируя преконвенционный, конвенционный и постконвенционный уровень одновременно, выбирая их в соответствии с ситуащией, студенты преимущественно находятся на высокой стадии их сформированности.

Ключевые слова: личность, моральное сознание, студент, метод, психосемантика, эмпирическое исследование, преконвенционный уровень, конвенционный уровень, постконвенционный уровень, поведение.

Постановка проблеми. Питання моральності, питання становлення моральної свідомості, питання моральної поведінки були актуальними у побутовій та науковій сферах споконвічно як у просторовому вимірі: від Древнього Сходу (Стародавній Сгипет, Шумеро-Вавілонська культура, стародавні Китай та Індія) до філософів Мілетської школи та Ефесту (Фалес, Анаксимандр, Анаксимен та ін.); у часовому вимірі: від Конфуція (551-479 рр. до н.е.), Мєн-цзи, Ван Чуна та ін. до нашого сьогодення (І.Д. Бех, Р.В. Павелків, М.Й. Боришевский, І. Булах, М. Савчин та ін.); у площині наукових шкіл та течій: від Веданти до сьогоднішніх концепцій особистісно-орієнтованого морального виховання; у духовній площині: від релігій Сходу до православ'я. Чому ж і досі це питання $є$ актуальним? Чому й досі ми жахаємось від «Надзвичайних новин», яких з часом існування людства менше не стає? Річ у тім, що психологам відомі, розроблені та впроваджені механізми й способи навчання і формування складних операційних дій (читання, письмо, рахунок тощо), людина навчилась створювати складні прилади, машини (комп'ютери, космічні апарати, штучний інтелект тощо), але людина не завжди керується моральними принципами та правилами, хоча вони 3 операційної точки зору - елементарні: не брати, не ображати, не бити, не вбивати... На що орієнтована поведінка особистості: на зовнішній чи внутрішній контроль? Як цей контроль зробити не на основі стимул-реактивної схеми, а на основі свідомої поведінки?

Відомо, що одним із дієвих способів формування свідомості та самосвідомості є метод переконання. Переконана особистість діє відповідно до своїх переконань, не залежно від зовнішніх чинників та наявності соціального контролю. Але напротивагу всіх педагогічних переконань на свідомість особи сильно впливає приклад, реальність. Не часто моральні переконання вихователя, вчителя, батьків і т.д. підтверджуються на практиці, в пеальному житті. Ось цього досягти досить важко, адже людську жадібність, заздрість, хитрість не можна заборонити законодавчим способом. Саме тому ми здійснили спробу дещо наблизитьсь до вирішення цієї «вічної» проблеми через призму психосемантичних особливостей моральної свідомості із суб' єктних позицій самої особистості.

Аналіз останніх досліджень і публікацій. Психосемантичний аспект пов'язаний із тим, як людина розуміє зміст морально-етичної інформації, яким чином вона категоризує не лише свої знання про моральність, а і ставлення до них. Тому дослідження процесів категоризації стало центром дискусії у психології розвитку вітчизняної психології, для якої базисною виявилася проблема засвоєння знакової системи. Категорія «значення» стала ключовою у теорії Л. Виготського, де він описував іï «як єдність спілкування й узагальнення» і вважав, що методом дослідження відношення думки до слова $є$ метод семантичного аналізу. Розвиток цих ідей ми бачимо в працях О. Леонтьєва, О. Лурії та багатьох інших сучасних дослідників, зокрема В. Петренко [1], О. Бондаренко [2], В. Васютинський [3], О. Польшина [4] та багато інших.

Досить змістовними у цьому ракурсі є дослідження В. Сєркіна [5] де він виокремлює такі методи психосемантичного дослідження: спостереження і бесіда; зображення або опис слів, станів, ситуацій, відносин; методи визначення понять; методи порівняння (розрізнення) стимулів; методи класифікації; методи суб'єктивного шкалювання; асоціативні експерименти; методи формування понять; семантичні диференціали (СД); методи особистісних конструктів; методи семантичних 
радикалів; методи опосередкованого дослідження значень; методи мікросемантичного аналізу; методи контекстної та семантичної реконструкції і конструювання; контент-аналіз глибинних семантичних ролей; методи порівняння і трансляції семантичних описів; формувальні і навчальні психосемантичні експерименти; лонгетюдні психосемантичні експерименти; побудова векторних моделей спрямованості семантичних описів; метод дослідження словника інтрацептивних відносин.

Використання психосемантичних методик дозволяє просто і зручно створити математичну модель індивідуальної свідомості - семантичний простір, як систему ознак, які описують об'єкти певної дійсності. Різні ознаки можна представити як координатні осі багатовимірного семантичного простору, об'єкти - як точки у цьому просторі, значення ознак цих об’єктів - як координати або проекції точок на осі, а відмінності між об’єктами - як відстані між точками. Методи експериментальної психосемантики традиційно використовуються для виявлення відносин людей до себе та інших.

Отже, психосемантичні методики, на нашу думку, найбільш адекватні для дослідження уявлень людини про різні об’єкти дійсності та її ставлення до них, що і є сутністю свідомості, в тому числі моральної.

Упродовж кількох останніх десятиліть захищено чимало (що також є свідченням актуальності цієї проблематики) докторських і кандидатських дисертацій 3 проблематики формування моральної свідомості, зокрема роботи Р. Павелківа, О. Безверхова, Н. Яцюк, О. Квашук, І. Цемрюк та багато інших. Ми ж, у своєму дослідженні будумо виходити із розуміння моральної свідомості за Р. Павелківим: «Моральна сфера - складний конструкт людської психіки та поведінки, в основі якого лежить унікальне утворення, що отримало назву моральної свідомості» [6].

Формулювання цілей статті. Представлення результатів емпіричного дослідження рівня сформованості моральних цінностей у свідомості студентів.

Виклад основного матеріалу дослідження. У вересні 2018 року на базі психологоприродничого факультету Рівненського державного гіманітарного університету було організоване емпіричне дослідження моральної свідомості з використанням діагностики розвитку моральної свідомості особистості Л. Кольберга. Тут сформулювано дев'ять дилем оціночного характеру норм і правил моралі. Використання методики дозволяє зробити висновок про стадії розвитку моральної свідомості особистості. Вибірку склали 43 студента денної форми навчання 2 курсу.

Відповідно до думки Л.Кольберга моральна свідомість у своєму розвитку проходить три рівні. Кожен рівень, у свою чергу має дві стадії: доморальний, конвенційний та автономний.

I. Доморальний рівень (преконвенційний). У своїй поведінці людина враховує прийняті в суспільстві правила і норми, що визначають поняття добра і зла. Однак при цьому вона орієнтується лише на власні фізичні або гедоністичні (пов'язані із задоволенням або невдоволенням) наслідки виконуваних дій (заохочення, покарання, фаворитизм тощо), а також на авторитет і владу тих, хто встановив ці правила і норми.

Стадія 1. Людина орієнтується на покарання і підпорядкування (покору), ії дії оцінюються як позитивні або негативні залежно від того, заохочено або покарано людину.

Стадія 2. Наївно інструментальна орієнтація. Морально виправданою вважається дія, яка водночас сприяє задоволенню потреб як індивіда, так і інших людей. Взаємодії людей розуміються як ринковий обмін «ти - мені, а я - тобі».

II. Конвенційний рівень. Людина у своїй поведінці підпорядковується прийнятим моральним вимогам і прагне відповідати моральним очікуванням групи (сім'ї, трудового колективу, організації, нації тощо).

Стадія 3. Орієнтація на еталонний зразок «доброго хлопця» чи «доброї дівчини», що існує у певній групі.

Стадія 4. Орієнтація на вимоги «закону і порядку». Людина поводиться так, а не інакше через те, що виконує свої обов'язки або обіцянки, контролює виконання встановленого порядку задля самого порядку.

III. Автономний (постконвенційний чи принциповий рівень). Людина прагне виявити i встановити для себе універсальні моральні цінності, які $є$ правильними незалежно від того, яка група людей підтримує їх, та незалежно від того, які стосунки у людини з відповідною групою людей.

Стадія 5. Внутрішня система принципів людини зорієнтована на соціальну домовленість, зумовлену офіційно прийнятою суспільною мораллю.

Стадія 6. Автономна мораль людини визначається універсальними етичними принципами справедливості, добра, віри, краси тощо.

Розглянувши рівні та стадії розвитку моральної свідомості, можна зробити висновок, що на преконвенційному рівні людина виконує вимоги, боячись покарання. На конвенційному рівні 
дотримання моралі визначається намаганням належати групі, суспільству, відповідати їх вимогам 3 метою самозбереження, на третьому рівні - автономному, людина добровільно обирає моральну поведінку, адже переконана, що жити їй потрібно згідно з нормами, прийнятими нею добровільно. Тобто на 6 стадії формуються стійкі моральні принципи, виконання яких забезпечується власною совістю, безвідносно до зовнішніх обставин і розумових міркувань.

У нашому випадку реціпієнту надавалась інструкція, де пропонувалось дати відповіді на запропоновані ділеми. При цьому наголошувалось, що жодна дилема не містить правильного, бездоганного рішення - будь-який варіант є прийнятним та має свої плюси і мінуси. Зверталась увага на обгрунтування переваг наданої відповіді.

Результати виконання завдань зібрані у середньогрупові показники розвитку моральної свідомості студентів, які відображено на рис. 1.

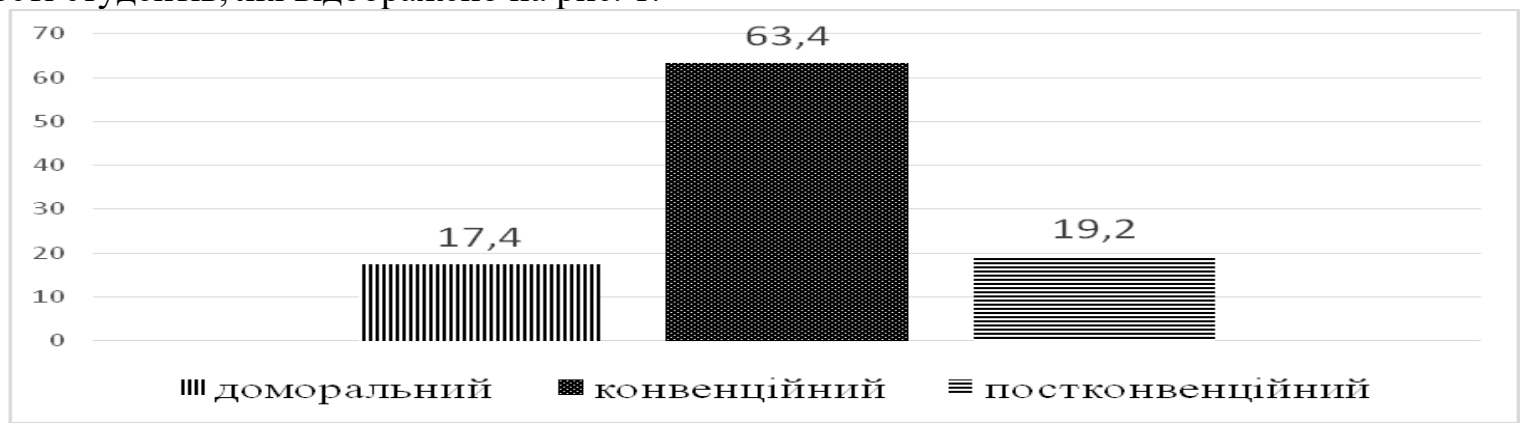

Рис.1. Середньогрупові показники рівнів розвитку моральної свідомості студентів (\%)

Як видно з представленої діаграми, найбільш сформованим у студентів $\epsilon$ конвенційний рівень моральної свідомості (63,4 \%), який виражає спрямованість студентів на відповідність соціальним нормам і правилам. На нашу думку, це позитивно корелює з колективістським полюсом культури українського суспільства (за моделлю Г. Хофстеде). Тут колективізм радше розуміється як тяжіння, передусім до вироблених традицій, правил і норм. Саме такий колективізм підносить важливість думки інших, їхню оцінку та схвалення, порушує питання самооцінки особистості, тоді як індивідуалізм ототожнюються, передусім, із самоприйняттям і самоцінністю.

Л. Засєкіна [7] з цього приводу зазначає, що для встановлення між особової взаємодії найбільш прийнятним є збалансований тип культури у полюсах індивідуалізм-колективізм. Тому вважаємо, що такій збалансованості відповідає постконвенційний рівень морального розвитку $(19,2 \%)$. Саме цей рівень забезпечує оптимальне самовираження особисті відповідно до своїх цінностей та уявлень про світ. Цей рівень морального розвитку більшою мірою тяжіє до виміру індивідуалізму культури. Найменш вираженим $є$ преконвенційний рівень розвитку $(17,4 \%)$, який виражає орієнтацію студентів у поняттях добра і зла, водночас відповідає більшою мірою власним цінностям, а не прийнятим у суспільстві нормам чи гедоністичним потребам.

Таким чином, результати теоретичного і емпіричного дослідження рівнів розвитку моральної свідомості студентів свідчать про те, що найбільш сформованим рівнем $є$ конвенційний рівень, який виражає спрямованість студентів на наслідування прийнятим у суспільстві нормам і правилам. Це значною мірою сприяє гармонійній міжособовій взаємодії студентів, водночас гальмує їх самовираження відповідно до власних цінностей. Такому самовираженню сприяє постконвенційний рівень, який водночас, $\epsilon$ недостатньо сформованим у студентів, що потребує подальшого комплексного дослідження структур різних стадій моральної свідомості.

За результатами описової статистики, було встановлено значення відповідних процентилів $\mathrm{i}$ визначено низький, середній і високий рівні преконвенційної, конвенційної і постконвенційної моральної свідомості. Середні значення відповідно до встановлених рівнів моральної свідомості на основі середньогрупових значень і стандартного відхилення відображено в таблиці 1.

Значення рівнів та ступенів моральної свідомості

Таблиия 1

\begin{tabular}{|c|l|c|c|c|}
\hline \multirow{2}{*}{ № 3/п } & Стадії моральної свідомості & \multicolumn{3}{|c|}{ Показники ступенів моральної свідомості } \\
\cline { 3 - 5 } & & низька & середня & висока \\
\hline 1 & преконвенційна & $0-9,75$ & $9,76-13,00$ & $13,01-27,00$ \\
\hline 2 & конвенційна & $0-40,00$ & $41,00-47,00$ & $48,00-61,00$ \\
\hline 3 & постконвенційна & $0-13,0$ & $14,0-18,00$ & $19,00-41,00$ \\
\hline
\end{tabular}


Слід зазначити, що кожен із студентів має по-різному виражені усі стадії моральної свідомості. Як зазначалося, найвищі показники серед вибірки усіх студентів має конвенційна стадія розвитку моральної свідомості. Водночас усі студенти також володіють попередньою стадією преконвенційною, розподіл студентів на цій стадії моральної свідомості відображено на рисунку 2.

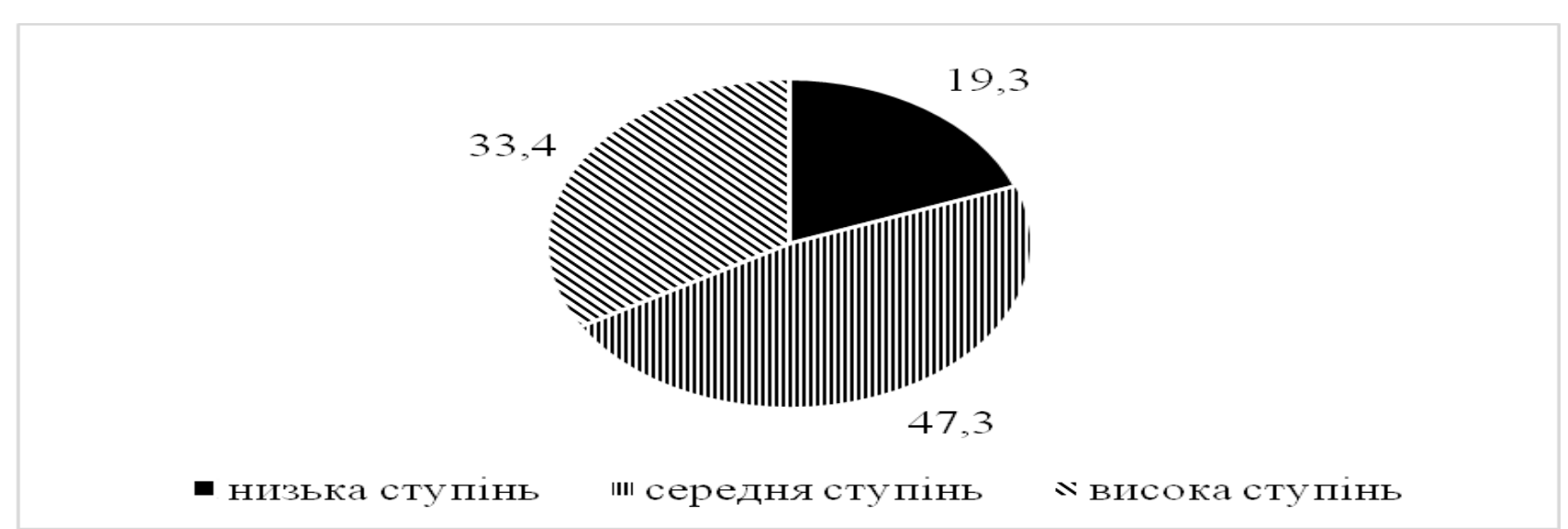

Рис. 2. Розподіл студентів з преконвенційним рівнем моральної свідомості (\%)

Найбільший відсоток студентів (47,3 \%) мають високий ступінь преконвенційної свідомості. Це свідчить, що у власній поведінці студенти орієнтуються на прийняті в суспільстві правила i норми, які визначають поняття добра і зла. Однак при цьому вони орієнтуються лише на власні фізичні або гедоністичні (пов'язані із задоволенням або невдоволенням) наслідки виконуваних дій (заохочення, покарання, фаворитизм тощо), а також на авторитет і владу тих, хто встановив ці правила і норми. Високий рівень преконвенційної свідомості свідчить про те, що провідним принципом для таких студентів є життєве правило: «я тобі - ти мені», відтворюючи так звану «кругову поруку» через сподівання отримати користь в майбутньому.

Розподіл студентів на конвенційній стадії морального розвитку (див. рис. 3) має подібний вигляд до преконвенційної стадії. Так, найвищий відсоток студентів $(43,6 \%)$ охоплює також високу ступінь конвенційної моральної свідомості. Студенти із цією стадією моральної свідомості підпорядковуються прийнятим моральним вимогам і прагнуть відповідати моральним очікуванням групи (сім'ї, трудового колективу, організації, нації тощо). Провідним гаслом цих студентів $\epsilon$ підпорядкування законам і порядку.

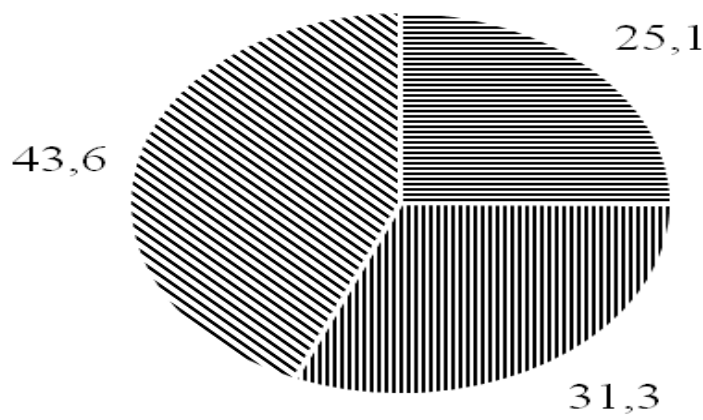

三низька ступінь пा середня ступінь $心$ висока ступінь

Рис. 3. Розподіл студентів з конвенційним рівнем моральної свідомості

На рисунку 4 показано результати розподілу опитаних з постконвенційним рівнем моральної свідомості. Майже однаковий відсоток студентів (35,2\%) володіє високим та середнім (36,8\%) ступенем постконвенційної моральної свідомості. Такі реципієнти намагаються встановити для себе універсальні моральні цінності, які є правильними незалежно від того, яка група людей підтримує їх, та незалежно від того, які їхні стосунки з відповідною групою людей. 


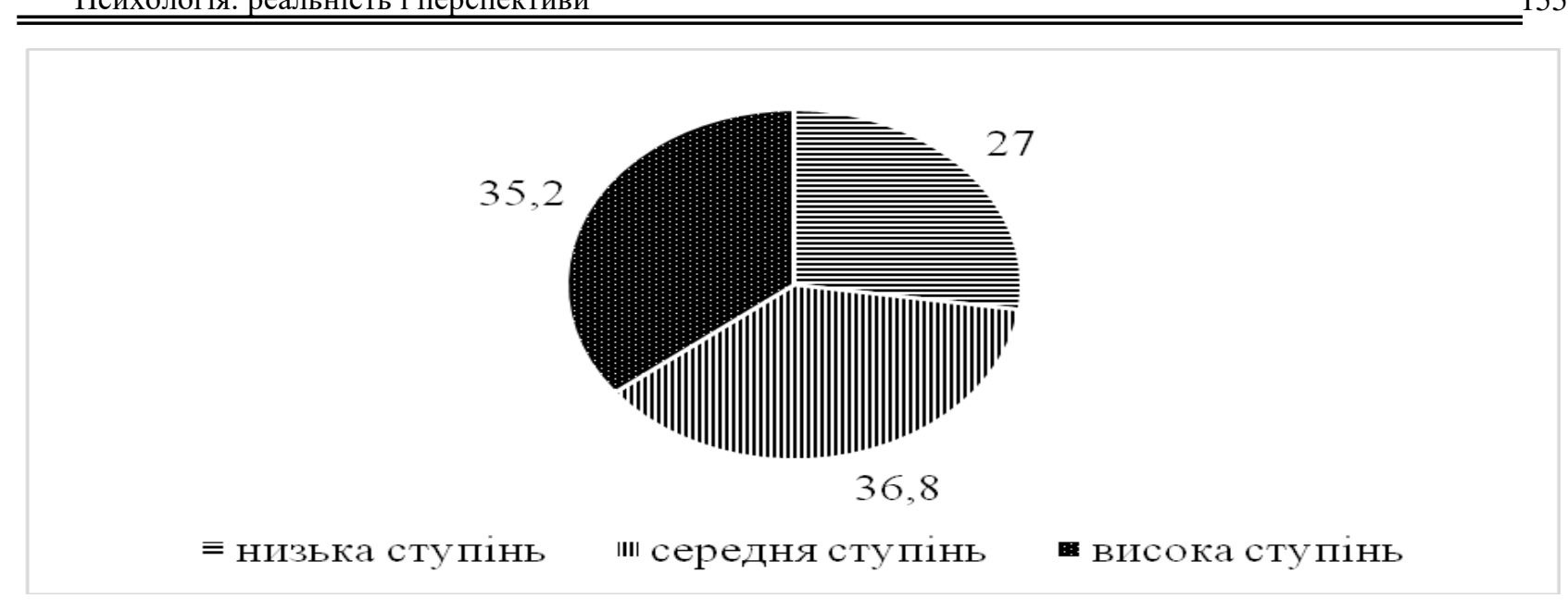

\section{Рис. 4. Розподіл студентів з постконвенційним рівнем моральної свідомості}

Висновки 3 даного дослідження і перспективи подальших розвідок. Отже студентська молодь представлена усіма стадіями рівня розвитку моральної свідомості: преконвенційна, конвенційна, постконвенційна. Всі вони виявляються переважно на високій стадії. На думку автора методики Л. Кольберга, особа може досягнути вищої стадії лише за умови, якщо вона пройшла всі попередні. Студенти демонструють різні рівні розвитку моральної свідомості залежно від актуальної ситуації. Водночас, афішуючи преконвенційний, конвенційний і постконвенційний рівень одночасно, обираючи їх відповідно до ситуації, студенти переважно знаходяться на високій стадії їх сформованості.

Подальшою перспективою нашої роботи вважаємо розроблення комплексної психологічної програми, спрямованої на розвиток моральної свідомості студентів з урахуванням особливостей юнацького віку та змістових особливостей преконвенційного, конвенційного і постконвенційного рівня розвитку моральної свідомості студентів.

\section{Список використаних джерел}

1. Петренко В. Основы психосемантики / В. Петренко. - 2-е изд., доп. - СПб. : Питер, 2005. $-480 \mathrm{c}$.

2. Бондаренко А. Язык. Культура. Психотерапия : сб. науч. ст. / А. Бондаренко. - Киев : Кафедра, 2012. - 416 с.

3. Васютинський В. Категорія «колективний суб'єкт» у феноменологічному дискурсі інтерсуб'єктної взаємодії / В. Васютинський // Наукові студії із соціальної та політичної психології : зб. ст. / АПН України, Ін-т соц. та політ. психології ; редкол. : С. Максименко, М. Слюсаревський та ін. - Київ : Міленіум, 2005. - Вип. 12 (15). - С. 23-38.

4. Польшина О. Психосемантичні особливості сприймання студентами народної орнаментальної символіки : автореф. дис. ... канд. психол. наук : 19.00.01 / О. Польшина ; Ін-т психології ім. Г. С. Костюка АПН України. - Київ, 2005. - 19 с.

5. Серкин В. Методы психосемантики : учеб. пособ. для студентов вузов / В. Серкин. - М. : Аспект-Пресс, 2004. - 207 с.: ил., табл.

6. Павелків Р. Розвиток моральної свідомості та самосвідомості в молодшому шкільному віці : автореф. дис. ... д-ра психол. наук : 19.00 .07 - Педагогічна та вікова психологія / Р. Павелків .Київ, 2005. - 40 с.

7. Засєкіна Л. Психологія значення: відбиття діяльнісного підходу у когнітивній парадигмі / Л. Засєкіна // Наукові записки. Серія: Психологія і педагогіка : зб. наук. пр. Нац. ун-ту «Острозька акад.». - Остріг, 2009. - Вип. 12. - С. 62-72.

\section{References}

1. Petrenko V. Osnovyi psihosemantiki / V. Petrenko. - 2-e izd., dop. - SPb. : Piter, 2005. $-480 \mathrm{~s}$.

2. Bondarenko A. YAzyik. Kultura. Psihoterapiya : sb. nauch. st. / A. Bondarenko. - Kyyiv: Kafedra, 2012. $-416 \mathrm{~s}$.

3. Vasyutinskiy V. Kategoriya «kolektivniy sub'€kt» u fenomenologichnomu diskursi intersub'єktnoï vzaєmodiï / V. Vasyutinskiy // Naukovi studiï iz sotsialnoï ta politichnoï psihologiï : zb. st. / 
APN Ukraïni, In-t sots. ta polit. psihologiï ; redkol. : S. Maksimenko, M. Slyusarevskiy ta in. - Kyyiv : Milenium, 2005. - Vip. 12 (15). - S. 23-38.

4. Polshina O. Psihosemantichni osoblivosti spriymannya studentami narodnoï ornamentalnoï simvoliki : avtoref. dis. ... kand. psihol. nauk : 19.00.01 / O. Polshina ; In-t psihologiï im. G. S. Kostyuka APN Ukraïni. - Kyyiv, 2005. - 19 s.

5. Serkin V. Metodyi psihosemantiki : ucheb. posob. dlya studentov vuzov / V. Serkin. - M. : Aspekt-Press, 2004. - 207 s.: il., tabl.

6. Pavelkiv R. Rozvitok moralnoï svidomosti ta samosvidomosti v molodshomu shkilnomu vitsi : avtoref. dis. ... d-ra psiholog. nauk : 19.00.07 - Pedagogichna ta vikova psihologiya / R. Pavelkiv. - Kyyiv, 2005. $-40 \mathrm{~s}$.

7. Zasєkina L. Psihologiya znachennya: vidbittya diyalnisnogo pidhodu u kognitivniy paradigmi / L. Zasєkina // Naukovi zapiski. Seriya: Psihologiya i pedagogika : zb. nauk. pr. Nats. un-tu «Ostrozka akad.». - Ostroh, 2009. - Vip. 12. - S. 62-72.

\section{O. O. Stavitskyi, D.O. Stavitskyi PSYCHOSEMANTIC ASPECTS OF THE STUDY MORAL CONSCIOUSNESS}

The article is devoted to the analysis of the results of the empirical study of levels of development of the moral consciousness of students of the humanitarian education profile using the psychosemantic method L. Kolberg (nine dilemmas of the evaluation nature of norms and rules of morality).

The psychosemantic aspect is related to how people understand the content of moral and ethical information, how it categorizes not only its knowledge of morality, but also the attitude towards them. Using psychosemantic techniques makes it easy and convenient to create a mathematical model of individual consciousness - semantic space, as a system of attributes describing objects of a given reality.

Student youth is represented by all stages of the level of development of moral consciousness: preconventional, conventional, postconventional. All of them are mainly at a high stage. It has been found that students demonstrate different levels of development of moral consciousness, depending on the actual situation. At the same time, posting the preconventional, conventional and postconventional levels simultaneously, choosing them according to the situation, students are mostly at the high stage of their formation.

The perspective of our work is the development of a comprehensive psychological program aimed at developing the students' moral consciousness, taking into account the peculiarities of the youth and the peculiarities of students.

Key words: personality, moral consciousness, student, method, psychosemantics, empirical research, preconventional level, convention level, postconventional level, behavior. 